\title{
Toxicity and Carcinogenicity of Androstenedione in F344/N Rats and B6C3F1 Mice
}

\author{
Chad R. Blystone I, Susan A. Elmore, Kristine L. Witt, David E. Malarkey, and Paul M.D. \\ Foster \\ National Toxicology Program, National Institutes of Environmental Health Sciences, National \\ Institute of Health, Department of Health and Human Services, Research Triangle Park, NC \\ 27709
}

\begin{abstract}
Androstenedione was marketed as a dietary supplement to increase muscle mass during training. Due to concern over long-term use, the NTP evaluated the subchronic and chronic toxicity and carcinogenicity of androstenedione in male and female $\mathrm{F} 344 / \mathrm{N}$ rats and $\mathrm{B} 6 \mathrm{C} 3 \mathrm{~F} 1$ mice. In subchronic studies, dose limiting effects were not observed. A chronic (two-year) exposure by gavage at 10,20 , or $50 \mathrm{mg} / \mathrm{kg}$ in rats and male mice, and 2,10 , or $50 \mathrm{mg} / \mathrm{kg}$ in female mice $(50$ $\mathrm{mg} / \mathrm{kg}$, maximum feasible dose) was conducted. Increased incidences of lung alveolar/bronchiolar adenoma and carcinoma occurred in the $20 \mathrm{mg} / \mathrm{kg}$ male rats and increases in mononuclear cell leukemia occurred in the 20 and $50 \mathrm{mg} / \mathrm{kg}$ female rats, which may have been related to androstenedione administration. In male and female mice, androstenedione was carcinogenic based upon a significant increase in hepatocellular tumors. A marginal increase in pancreatic islet cell adenomas in male $(50 \mathrm{mg} / \mathrm{kg})$ and female $(2,10,50 \mathrm{mg} / \mathrm{kg})$ mice was considered to be related to androstenedione administration. Interestingly, incidences of male rat Leydig cell adenomas and female rat mammary gland fibroadenomas decreased. In conclusion, androstenedione was determined to be carcinogenic in male and female mice, and may have been carcinogenic in rats.
\end{abstract}

\section{Keywords}

Androstenedione; Rat; Mice; Cancer; Two-Year Bioassay; Toxicity

\section{Introduction}

Androstenedione is a weak androgen steroid hormone normally produced in both males and females to be converted to a more potent androgen or estrogen. It was marketed as a dietary supplement to aid in increasing muscle mass during training. In 2004 androstenedione was banned for sale by the Anabolic Steroid Control Act, although illegal use may continue today. Androstenedione exposure levels are not available, but they likely varied among users

\footnotetext{
TTo whom correspondence should be addressed: National Toxicology Program, NIEHS, PO Box 12233 (MD K2-13), Research Triangle Park, NC 27709 blystonecr@niehs.nih.gov, Phone: 1-919-541-2741, Fax: 1-919-541-4255.

Publisher's Disclaimer: This is a PDF file of an unedited manuscript that has been accepted for publication. As a service to our customers we are providing this early version of the manuscript. The manuscript will undergo copyediting, typesetting, and review of the resulting proof before it is published in its final citable form. Please note that during the production process errors may be discovered which could affect the content, and all legal disclaimers that apply to the journal pertain.

This article may be the work product of an employee or group of employees of the National Institute of Environmental Health Sciences (NIEHS), National Institutes of Health (NIH), however, the statements, opinions or conclusions contained therein do not necessarily represent the statements, opinions or conclusions of NIEHS, NIH or the United States government

Conflict of interest The authors declare no conflicts of interest.
} 
and may have followed a cyclic pattern of prolonged use with intermittent recovery periods. Oral doses of androstenedione ranged from 100 to as high as $1,200 \mathrm{mg} /$ day, which equates on per weight basis to 1.4 to $17.1 \mathrm{mg} / \mathrm{kg}$ per day for a $70 \mathrm{~kg}$ person (Bahrke and Yesalis, 2004).

The effect of androstenedione supplements on circulating hormones and increasing muscle mass is variable and is likely affected by age, sex, exposure time, and dose. Administration of $300 \mathrm{mg}$ androstenedione/day for up seven days (Leder et al., 2000) or $300 \mathrm{mg}$ androstenedione/day for 28 days (Brown et al., 2004b) increased serum concentrations and excretion of androgens in men. However, administration of $200 \mathrm{mg}$ androstenedione/day for 28 days (Beckham and Earnest, 2003) or $300 \mathrm{mg}$ androstenedione/day for 8 weeks (King et al., 1999) did not increase serum testosterone levels in men. Prolonged androstenedione exposure to men ( $200 \mathrm{mg} /$ day for 12 weeks) elevated serum concentrations of androstenedione, estradiol, and estrone, but not testosterone (Broeder et al., 2000). Serum androstenedione and testosterone concentrations rise considerably in women compared to men after administration of androstenedione, likely due to the low concentrations of androgens normally circulating in women (Brown et al., 2004a; Leder et al., 2002). Significant effects on muscle mass gain have not been found in men after androstenedione administration, except following a large dose $(1,500 \mathrm{mg} / \mathrm{day}$ for 12 weeks) of androstenedione given to hypogonadal men, which increased circulating levels of androstenedione and testosterone at the end of the exposure period (Jasuja et al., 2005).

Only a few studies have examined the carcinogenic or tumor promoter activity of androstenedione. Male Marsh-Buffalo mice, injected subcutaneously one to two times per 2month period, had increased numbers of fibrosarcomas at 18 months (Bischoff, 1957). Following the induction of mammary gland carcinoma in ovariectomized rats with the known carcinogen 7,12-dimethylbenz[a]anthracene, administration of androstenedione led to increased tumor size compared to the size of tumors induced in ovariectomized controls (Dauvois and Labrie, 1989). This effect was blocked by an aromatase inhibitor, indicating that conversion of androstenedione to estradiol was required for tumor enhancement. The androstenedione precursor DHEA produces hepatocellular carcinomas in rats and rainbow trout (Metzger et al., 1995; Orner et al., 1995; Rao et al., 1992). Androstenedione metabolites that are more potent androgens or estrogens, such as testosterone, estrone, or estradiol, are known carcinogens (Beamer et al., 1988; IARC, 1987; NTP, 2002).

Androgens are generally not considered to be mutagenic, clastogenic, or aneugenic. Mutagenicity was not seen with androstenedione $(500 \mu \mathrm{g} / \mathrm{disc})$ in a spot test using $S$. typhimurium strain TA1538, with and without induced rat liver S9 enzymes (McKillop et al., 1983). A more potent androgen, testosterone (500 $\mu \mathrm{g} / \mathrm{plate})$, was negative in $S$. typhimurium strains TA100, TA1535, and TA1538, with and without rat liver S9 (Ingerowski et al., 1981). Testosterone $(100 \mu \mathrm{M})$ was tested in cultured Chinese hamster Don cells for induction of mitotic disruption, and no mitotic disturbances were noted following a 7-hour treatment period (Wheeler et al., 1986). Tsutsui et al. (1995) tested testosterone and testosterone propionate in Syrian hamster embryo (SHE) cells for induction of chromosomal aberrations, anueploidy, and gene mutations; all test results were negative (Tsutsui et al., 1995).

Previously, the NTP studied the synthetic anabolic steroid oxymetholone in F344/N rats after chronic exposure, and found it to be carcinogenic in female rats based upon increased neoplasms in the liver, lung, and skin, but no clear neoplastic effects were seen in male rats (NTP, 1999). Due to the concern for adverse effects following prolonged use of androstenedione and the lack of chronic toxicity and carc inogenicity data, subchronic 
toxicity studies with androstenedione were conducted by the NTP, followed by an evaluation of its chronic toxicity and carcinogenicity in F344/N rats and B6C3F1 mice.

\section{Materials and Methods}

\subsection{Animals and Dosing}

Androstenedione (CAS\# 63-05-8, Lot H408, Steraloids, Inc., Newport, RI) was identified by infrared (IR) and proton and carbon-13 nuclear magnetic resonance (NMR) spectroscopy. The purity was determined to be $>98 \%$ by gas chromatography and high-performance liquid chromatography. Dose formulations consisted of androstenedione in $0.5 \%$ methylcellulose (Sigma Aldrich, Saint Louis, MO), which homogeneity, dosing feasibility, resuspendability, and stability were confirmed. Dose formulations were evaluated prior to the start of the subchronic and chronic study and evaluated again three times during the subchronic study and every two-three months during the chronic study. The current studies were limited to a high dose of $50 \mathrm{mg} / \mathrm{kg}$ due to dosing feasibility (i.e. ability to gavage administer the formulation) at the high dose. Dose formulations were within $10 \%$ of target.

The studies were conducted at Southern Research Institute (Birmingham, AL). Male and Female B6C3F1 mice and Fisher F344/N rats were purchased from Taconic Farms, Inc (Germantown, NY). Animals were quarantined 12-15 days and were 5-6 weeks old at the start of dosing. NTP-2000 diet (Rao, 1996) and water were provided ad libitum. Animals were randomly assigned into dose groups of approximately similar initial mean body weights. Similar sexes were grouped house (5/cage in subchronic studies; $5 /$ cage for females and $3 /$ cage for male rats in chronic studies), except for male mice. The gavage dose was calculated using the most recent body weight and dosing volume was $5 \mathrm{~mL} / \mathrm{kg}$ for rats and $10 \mathrm{~mL} / \mathrm{kg}$ for mice. Rats and mice were gavaged 5 days/week. Studies were conducted in accordance with U.S. Public Health Service animal care policy and the Guide for the Care and Use of Laboratory animals. In addition, these studies were conducted in compliance with Good Laboratory Regulations established by the Food and Drug Administration.

\subsection{Subchronic study}

Male and female rats and mice ( $\mathrm{n}=10 / \mathrm{sex} /$ species) were dosed $0,1,5,10,20,50 \mathrm{mg} / \mathrm{kg} / \mathrm{day}$ androstenedione for 14 weeks. Animals were weighed at the beginning of the study, weekly during androstenedione administration, and then at necropsy. An additional ten rats/sex/dose were added to the study in order to collect blood, via the retro-orbital sinus, for hematology and clinical chemistry on day four and twenty four. Blood was also collected during necropsy for hematology (rats and mice) and clinical chemistry (rats only). At necropsy, the heart, right kidney, liver, lung, right testis, thymus, and uterus were weighed. Tissues for histological evaluation were fixed and preserved in $10 \%$ neutral buffered formalin, except the testis and epididymides, which were initially fixed in modified Davidson's solution prior to being transferred to formalin and the eyes, which were fixed in Davidson's solution.

Tissues were trimmed, embedded, sectioned to 4-6 $\mu \mathrm{m}$ slices, and stained with hematoxylin and eosin. A complete histopathologic evaluation was conducted on all tissues from the control and $50 \mathrm{mg} / \mathrm{kg}$ dose group. If a compound-related effect was found in the high dose, lower dose groups were examined until a no effect level was identified.

At the end of the 14 week studies, samples were collected for sperm motility, spermatid head and sperm count, and vaginal cytology evaluations on rats and mice administered 0,10 , 20 , or $50 \mathrm{mg} / \mathrm{kg}$. For 12 consecutive days prior to scheduled terminal sacrifice, vaginal smears were collected and cells were stained with toludine blue. Relative numbers of leukocytes, nucleated epithelial cells, and large squamous epithelial cells were determined and used to ascertain estrous cycle stage (i.e., diestrus, proestrus, estrus, and metestrus). 
Homogenization-resistant spermatid nuclei and sperm count was measured using a hemacytometer and sperm motility was determined by counting motile and nonmotile sperm for five fields per slide by two observers.

\subsection{Chronic study}

In the chronic study, male and female rats and male mice ( $\mathrm{n}=50 / \mathrm{sex} / \mathrm{species})$ were dosed with 10,20 , and 50 androstenedione $\mathrm{mg} / \mathrm{kg} / \mathrm{day}$ and female mice were dosed at 2, 10, 50 $\mathrm{mg} / \mathrm{kg} /$ day for 104-106 weeks ( 2 years). The lower doses selected for the female mice were based upon suspected ovarian atrophy in the 14-week study (which later was not confirmed by a more detailed investigation). Animals were weighed initially, weekly for the first 13 weeks, then monthly for the rest study, and on the day of necropsy. Complete necropsies and microscopic examinations were performed on all animals. Organs were examined for visible lesions and tissues were preserved as mentioned in section 2.3. Complete histopathology was performed on all animals. More details of the pathology evaluation are available elsewhere (NTP, 2010).

Severity grades for glandular hyperplasia of clitoral gland were based on a semiquantitative evaluation of the amount of sebaceous glands in a section: grade $0=$ none to only one or two small foci of glands; grade $1=$ three or five small clusters of sebaceous glands; grade $2=$ several moderately sized clusters or at least one larger cluster; grade $3=$ several moderate or one large area of sebaceous glands. Severity of duct dilatation was graded on a semiquantitative estimate of the percentage of a $4 \times$ microscopic field that was occupied by the dilated ducts of the clitoral glands: grade $0=$ neither gland occupied more than $15 \%$ of the microscopic field; grade $1($ minimal $)=$ at least one gland occupied $16 \%$ to $25 \%$ of the microscopic field; grade 2 (mild) = at least one gland occupied $25 \%$ to $31 \%$ of the microscopic field; grade 3 (moderate) $=$ at least one gland occupied $31 \%$ to $75 \%$ of the microscopic field; grade 4 (marked) $=$ at least one gland occupied $75 \%$ to $100 \%$ of the microscopic field.

\subsection{Genetic toxicity}

The genetic toxicity of androstenedione was assessed in bacterial mutagenicity assays and rodent erythrocyte micronucleus assays that measure chromosomal damage induction. Briefly, coded samples of androstenedione were tested for induction of gene mutations (histidine reversion) in multiple strains of bacteria (Salmonella typhimurium TA 97, TA 98, TA 100, and TA 1535, and Ecsherichia coli WP2 uvrA/pKM101), with and without exogenous metabolic activation provided by induced male Sprague Dawley rat or Syrian hamster liver enzymes and cofactors (S9 mix) (for detailed protocol, see (Zieger et al., 1992)). In two independent experiments, androstenedione was incubated with the bacterial tester strains in buffer or S9 mix for 20 minutes at $37^{\circ} \mathrm{C}$. In the first study, concentrations of androstenedione ranged from 100 to $10,000 \mu \mathrm{g} /$ plate and both $10 \%$ and $30 \%$ rat and hamster S9 were used with S. typhimurium strains TA97, TA98, TA100, and TA1535. In the second study, Salmonella strains TA98 and TA100 were tested, along with Escherichia coli strain WP2 $u v r A / p K M 101 ; 10 \%$ induced rat liver S9 was used to provide metabolic activation. Each trial consisted of triplicate plates of concurrent positive and negative controls and of at least five doses of androstenedione. In the absence of apparent cytotoxicity in the first study, a top concentration of 10,000 ug/plate was used for all tester strains. In the second study, conducted with a sample from the same lot of androstenedione used in the 2-year cancer bioassay, the highest concentrations ranged from $3500-10,000 \mathrm{ug} /$ plate across strains.

Evaluation of the ability of androstenedione to induce chromosomal damage in vivo was conducted in two independent rodent micronucleus assays. In the first test (protocol details in (Shelby et al., 1993)), male Fisher 344 rats received 312 or $625 \mathrm{mg} / \mathrm{kg}$ androstenedione 
dissolved in corn oil by gavage three times at $24 \mathrm{hr}$ intervals; vehicle control rats received corn oil only. Two cyclophosphamide positive control groups were included (15 or $25 \mathrm{mg}$ / $\mathrm{kg}$ ). Twenty-four hours after the final dosing, smears of the bone marrow cells obtained from the femurs were prepared. Air-dried slides were fixed, stained with acridine orange, and coded; 2000 polychromatic erythrocytes (PCE, or reticulocytes) were scored per animal for frequency of micronucleated cells. A second evaluation of micronucleus frequencies was conducted in mice (protocol details in (Witt et al., 2000)). At the termination of the 14-week toxicity study with androstenedione $(1-50 \mathrm{mg} / \mathrm{kg} /$ day by gavage), blood was obtained from male and female $\mathrm{B} 6 \mathrm{C} 3 \mathrm{~F} 1$ mice, and smears were immediately prepared and fixed in absolute methanol. The frequency of micronucleated cells was determined in 2,000 normochromatic (mature) erythrocytes (NCEs) per animal. In addition to assessment of micronucleus frequencies, the percentage of polychromatic erythrocytes (PCEs) among eryt hrocytes was determined in both the rat and the mouse studies as a measure of bone marrow toxicity.

\subsection{Statistics}

Survival was calculated using the methods of (Kaplan and Meier, 1958) and dose related effects were analyzed using Cox's method (Cox, 1972) for testing two groups for equality and Tarone's (Tarone, 1975) life table test for trends. Animals that died from non-natural causes (e.g. dosing accident) were not used in the analysis. The Poly-k test (Bailer and Portier, 1988; Portier and Bailer, 1989) was used to analyze neoplasm and non-neoplasm lesion incidence, which used a survival-adjusted quantal response procedure. Organ and body weight data were analyzed by parametric methods (Dunnett, 1955; Williams, 1971, 1972). Spermatid and spermatozoa data were analyzed using non-parametric methods (Shirley, 1977). Trends were analyzed using Jonckheere's test and if a trend was not evident, Dunnett test was used instead of Shirley. Outliers were identified by the Dixon and Massey test. Vaginal cyclicity data were arcsine transformed and analyzed by multivariate analysis of variance (Morrison, 1976). Proportions of regularly cycling females in each dose were compared to the control group using a Fisher's exact test. For the micronucleus assays, data are presented as the mean of all animals within a dose group ( \pm standard error). The frequency of micronucleated cells was analyzed for increasing trend over exposure groups using a one-tailed Cochran-Armitage trend test (alpha $=0.05$ ), followed by pairwise comparisons between each exposure group and the control group. To correct for multiplicity, a test was considered positive if 1 ) the trend test $\mathrm{p}$ value was $\leq 0.025$ and 2 ) the $\mathrm{p}$ value for any single exposure group was $\leq 0.025 / \mathrm{k}$ where $\mathrm{k}=$ the number of exposure groups. For more information relating to statistical analysis, refer to (NTP, 2010).

\section{Results}

\subsection{Subchronic Study}

3.1.1 F344/N Rats-Survival, hematology, and clinical chemistry were considered to be unaffected and no gross or histopathologic lesions were attributed to androstenedione administration. Androstenedione increased female body weight gain (Table 1), but did not increase male body weight or body weight gain. There was no effect on estrous cycle length or time of estrous stages by androstenedione administration. Although spermatid concentrations were unaffected by androstenedione administration, there was a significant decrease in cauda epididymal sperm concentrations (Table 2).

3.1.2 B6C3F1 Mice-Survival, body weight and body weight gain, and hematology were unaffected by androstenedione administration. There was a dose related increase in adrenal $\mathrm{X}$-zone atrophy and decrease in X-zone cytoplasmic vacuolization in female mice while body weight or weight gain was unaffected (Table 1). Sperm motility was decreased in the 
$50 \mathrm{mg} / \mathrm{kg}$ dose group (Table 2). Bone marrow hyperplasia was significantly increased in the 5 and $50 \mathrm{mg} / \mathrm{kg}$ male mouse groups, which was characterized by an increase of immature cells in the marrow cavity of the femur. This effect on the bone marrow was not associated with any hematology results.

\subsection{Chronic Study}

3.2.1 F344/N Rats-Survival was increased in the $10 \mathrm{mg} / \mathrm{kg}$ male group $(\mathrm{p}=0.018)$ and there were no effects on survival in the other male dose groups or in the female rats. Body weights of treated males were similar to the control. Female body weights in the 20 and 50 $\mathrm{mg} / \mathrm{kg}$ dose groups were generally greater than controls after week 17 and week 9 , respectively, and on average were greater than controls over selected time periods; percent increase over control for $10,20,50 \mathrm{mg} / \mathrm{kg} /$ day female groups: weeks 1-13: $0 \%, 1 \%, 5 \%$; weeks $14-52: 3 \%, 9 \%, 16 \%$; weeks $53-101: 1 \%, 6 \%, 9 \%$ respectively.

In female rats there was a positive trend $(\mathrm{p}=0.029)$ in mononuclear cell leukemia (MCL) with the 20 and $50 \mathrm{mg} / \mathrm{kg}$ dose groups increased over control (Table 3 ). There was a nearly significant $(p=0.052)$ negative trend in incidence of MCL in male rats with the 20 and 50 $\mathrm{mg} / \mathrm{kg}$ doses groups significantly decreased from controls. Mononuclear cell leukemia was characterized by a proliferation of neoplastic large granular lymphocytes in the spleen and liver and in the blood vessels of many other tissues. The incidence alveolar/bronchiolar adenoma increased in the male rat $20 \mathrm{mg} / \mathrm{kg}$ dose group and one carcinoma was observed in the $50 \mathrm{mg} / \mathrm{kg}$ dose group (Table 3).

In the testis, the incidences of interstitial cell adenoma (including bilateral) occurred with a negative trend $(\mathrm{p}<0.001)$, and the incidence was significantly decreased in $50 \mathrm{mg} / \mathrm{kg}$ males (Table 3). Interstitial cell adenomas were characterized by small to large nodules of interstitial cells that compressed the surrounding seminiferous tubules; larger neoplasms effaced much of the testicular architecture. Neoplastic cells had an abundant, pale, eosinophilic to amphophilic, finely vacuolated cytoplasm, fairly well-defined cell borders, and a central nucleus. In some adenomas, large areas were composed of these basophilic cells, having a smaller round to oval nucleus with stippled chromatin and a sparse amount of eosinophilic cytoplasm with indistinct borders.

In female rats, there was a decreasing trend $(p<0.001)$ in mammary gland fibroadenoma incidences and the incidence was significantly decreased in 20 and $50 \mathrm{mg} / \mathrm{kg}$ females compared to controls (Table 3). Furthermore, the incidences of multiple fibroadenomas were decreased. The incidences of fibroadenoma, adenoma, or carcinoma (combined) were significantly decreased in 20 and $50 \mathrm{mg} / \mathrm{kg}$ females, mainly due to the decreased incidences of fibroadenoma, relative to control females. Fibroadenomas consisted of both ductular and/ or alveolar epithelium and fibrous connective tissue. Smaller neoplasms usually contained a higher proportion of glandular tissue, and larger ones consisted almost entirely of connective tissue. In larger neoplasms, the majority of the neoplasm was composed of fibrous tissue with only a few atrophied glands remaining. The central portions of larger neoplasms were often necrotic, and only faint outlines of glands were identified.

The incidence of mammary gland hyperplasia was significantly decreased in all dosed female groups, and the incidences of mammary gland cyst were significantly decreased in 10 and $50 \mathrm{mg} / \mathrm{kg}$ females (Table 3). Mammary gland hyperplasia was characterized by increased layers of ductular and/or alveolar epithelial cells, enlarged lobules, and enlarged ducts filled with secretory product. Alveolar epithelial cells often had a vacuolated cytoplasm. Mammary gland cysts were characterized by large dilated ducts that were more prominently distended with secretory product than the majority of the enlarged ducts in the hyperplastic mammary glands. 
3.2.2 B6C3F1 Mice-Female survival was unaffected by androstenedione dosing. In males, there was a marginal increase in survival $(p=0.059)$ in the male $10 \mathrm{mg} / \mathrm{kg}$ dose group and the other dose groups were not affected. Dosed male body weights were similar to controls and female body weights were decreased by approximately $6 \%$ in the $50 \mathrm{mg} / \mathrm{kg}$ dose group.

Hepatocellular neoplastic incidence increased in both dosed male and female mice (Table 4). There were positive trends $(p=0.024)$ in the incidences of hepatocellular adenoma in male and female mice, and the incidences in the $50 \mathrm{mg} / \mathrm{kg}$ groups were significantly increased. The incidences of hepatocellular carcinoma in all dosed groups of females were significantly increased. There were significantly increased incidences of multiple hepatocellular adenoma (males and females) and multiple hepatocellular carcinoma (females). The incidences of hepatoblastoma and multiple hepatoblastoma were marginally increased in dosed males. There was a positive trend in the incidences of hepatocellular adenoma, hepatocellular carcinoma, or hepatoblastoma (combined) in males, and the incidence in the $50 \mathrm{mg} / \mathrm{kg}$ group was significantly increased.

Hepatocellular adenomas were characterized by well-circumscribed nodular lesions larger than a liver lobule and composed of well-differentiated hepatocytes of variable size and tinctorial properties. The cytoplasm varied among eosinophilic, basophilic, vacuolated, or a mixture. Normal lobular architecture was lost, and hepatic plates at the margins impinged at sharp angles to the surrounding normal liver plates. Central veins and portal tracts were not readily apparent, although some were trapped in the expanding mass at the periphery. Some adenomas were solid and others had plates one to three cell layers thick. Cellular atypia and mitotic figures were occasionally observed. Focal areas of fatty change (lipidosis) within adenomas were occasionally noted. Hepatocellular carcinomas were not always well demarcated and often had irregular borders as cells infiltrated into the surrounding parenchyma. Cellular atypia and mitotic figures were common. Nucleoli were often enlarged and multiple. Cells had eosinophilic, basophilic, vacuolated, or mixed tinctorial appearances. Some carcinomas had a solid growth pattern, while a trabecular pattern was also common. Necrosis was noted in some tumors. Incidence of pancreatic islet adenoma increased in 50 $\mathrm{mg} / \mathrm{kg}$ males and 10 and $50 \mathrm{mg} / \mathrm{kg}$ females, and a decreased incidence of hyperplasia occurred in $50 \mathrm{mg} / \mathrm{kg}$ males, but these differences were not statistically significant (Table 5). In $50 \mathrm{mg} / \mathrm{kg}$ males, first incidence of pancreatic islet adenoma decreased with dose, and one animal had multiple pancreatic islet adenomas. Pancreatic islet adenomas were characterized by an increased size of a single islet with a more uniform population of cells having a pale pink, lacy cytoplasm and central nuclei with a delicate chromatin pattern.

The incidence of malignant lymphoma (lymphocytic, histiocytic, mixed, or undifferentiated) was significantly decreased in $50 \mathrm{mg} / \mathrm{kg}$ female mice. Malignant lymphoma was characterized by a proliferation of sheets of neoplastic lymphocytes in various organs, particularly the liver and spleen. Variable types of malignant lymphoma were represented.

Several non-neoplastic changes in female mice were noted in the clitoral gland, kidney, and submandibular gland (Table 6). Within the clitoral gland, glandular hyperplasia was characterized by increased amounts of sebaceous glands located around the ducts. Individual sebaceous gland cells were of normal size and tinctorial staining. Duct dilatation was characterized by an increase in the size and number of duct profiles. The ducts were lined by a keratinizing squamous epithelium, although the lining was often attenuated and consisted of a single layer of flattened squamous epithelial cells. The dilated duct contents were composed of pale, basophilic, amorphous material and keratin debris, although the cyst contents were often lost in processing. 
In the female mouse kidney, glomerular metaplasia increased in the $50 \mathrm{mg} / \mathrm{kg}$ dose group (Table 6). Glomerular metaplasia was characterized by a cuboidal appearance of the parietal epithelium of Bowman's capsule as compared to the normally flattened epithelium of vehicle control female mice. The cuboidal appearance of the epithelial cells involved more than $50 \%$ of the surface of the parietal epithelium of a glomerulus. The parietal epithelium of Bowman's capsule in control male mice is predominantly cuboidal, whereas this epithelium in control female mice has a predominantly flattened or squamoid appearance; a normal sexual dimorphism in this species (Figure 1).

Cytoplasmic alteration was increased in the submandibular salivary gland for the dosed female mice groups (Figure 2). This lesion was characterized by an increase in prominence and size of the convoluted ducts due to increased amounts of eosinophilic granular material in the cytoplasm of the duct epithelial cells. In addition, the nuclei of cells with cytoplasmic alteration tended to be more basally located within the cytoplasm. The appearance was similar to the submandibular salivary gland of male mice, as the granular ducts in male mice normally exhibit a sexual dimorphism with increased amounts of granular eosinophilic material in the cytoplasm and a more basilar location of nucleus beginning at approximately 20 days of age.

\subsection{Genetic Toxicity}

Androstenedione was not mutagenic in either of two independent bacterial mutation assays conducted with and without induced rat or hamster liver metabolic activation enzymes. In vivo, no statistically significant increases in the frequencies of micronucleated PCEs (reticulocytes) were observed in bone marrow of male F344/N rats administered androstenedione ( 312.5 or $625 \mathrm{mg} / \mathrm{kg}$ ) by gavage once daily for 3 days. Following 3 months of androstenedione administration ( 1 to $50 \mathrm{mg} / \mathrm{kg}$ ), androstenedione administration did not affect the frequency of micronucleated NCEs in male B6C3F1 mice. In female mice, a small increase in the frequency of micronucleated NCEs was observed at the highest dose tested $(50 \mathrm{mg} / \mathrm{kg})$; although not significantly elevated above the vehicle control $(\mathrm{P}=0.0142$; significance set at $\mathrm{p} \leq 0.005)$, this increase resulted in a significant trend $(\mathrm{P}=0.001)$, and the test in female mice was therefore judged to be equivocal (Table 7). No significant changes in the percentages of PCEs among total erythrocytes were seen in either the rats or mice, suggesting no androstenedione-associated toxicity in the bone marrow.

\section{Discussion}

Prior to the banning of over-the-counter sales, androstenedione was used as a dietary supplement by individuals who likely believed it would increase muscle mass during training. Due to concern for adverse health effects associated with its chronic use, the NTP conducted genetic, subchronic, and chronic toxicity studies of androstenedione in male and female rats and mice. The health effects of androstenedione will vary since androstenedione is an androgenic hormone that can be metabolized to a more potent androgen (e.g., testosterone) or to an estrogen, and different hormonal effects may occur depending on the metabolism and presence of steroid receptors within a specific tissue, which may vary with the age and sex of the animal.

In the 14-week studies, androstenedione did not demonstrate any dose-limiting toxicity effects in male and female rats and mice. Female rat body weights increased compared to the vehicle controls in both the 3-month and 2-year studies. A similar result occurred with oxymetholone, an androgenic anabolic steroid, which increased female rat body weights in subchronic and chronic studies (NTP, 1999). The increase in female rat body weights by androstenedione may be due to increased muscle mass, but neither muscle mass nor adipose mass were evaluated. The increased incidences of adrenal gland X-zone atrophy and X-zone 
cytoplasmic vacuolization seen in female mice after a 14-week exposure indicate that androstenedione, or a metabolite, had an androgenic effect. Regression of the adrenal Xzone in female mice normally occurs rapidly during the first pregnancy. Regression of the $\mathrm{X}$-zone in female mice can be stimulated by administration of androgens and can be delayed in males via castration (Holmes and Dickson, 1971; Tomooka and Yasui, 1978).

The reduction in sperm concentration in the rat cauda epididymis that occurred in the 3month study, in the absence of effects on spermatid numbers, suggests androstenedione may be interfering with sperm maturation. This effect is different from previous studies which observed a decrease in spermatid and spermatozoa concentrations. Administration of testosterone or estrogen via implants decreases spermatid concentrations within the testes and results in reduced fertility (Robaire et al., 1979; Robaire et al., 1984) and the anabolic steroid oxymetholone, reduced sperm concentrations in the epididymides and spermatid numbers (NTP, 1999). Sperm motility in male mice was significantly decreased at the top dose, and similarly, oxymetholone reduced male mouse sperm motility (NTP, 1999). Since sperm motility is achieved within the epididymis, androstenedione administration may also have affected sperm maturation in male mice. These effects indicate a potential for exogenous androstenedione to produce adverse effe fertility and reproductive performance. The genetic toxicity studies in bacteria and cts on male rodents reported here were negative, with the exception of an equivocal response in the peripheral blood micronucleus test in the high dose female mice exposed to androstenedione for 14 weeks. These results are in agreement with other published genetic toxicity test results (McKillop et al., 1983).

In the chronic study, there were statistically significant increased incidences of MCL, a common neoplasm in female F344/N rats (Haseman et al., 1998). Due to the low incidence in vehicle controls (10\%) compared to the historical range for all routes (8\% to $40 \%$; mean, $22 \%$ ) the relationship of this increased incidence to androstenedione administration was uncertain. Androstenedione also significantly increased the incidence of alveolar/bronchiolar adenoma or carcinoma (combined) in mid-dose male rats. Since these lung neoplasms were only marginally increased in the mid-dose $(20 \mathrm{mg} / \mathrm{kg})$ group and there was no reduction in survival or body weight in the $50 \mathrm{mg} / \mathrm{kg}$ group, it is unclear if the marginally increased incidence in the mid-dose group was compound related because of the lack of a dose response.

Interestingly, there were significant decreases in the incidences of mammary gland hyperplasia, mammary gland cysts, and mammary gland adenomas in female rats in the chronic study, which suggests that androstenedione administration ameliorated these lesions' endocrine mechanism(s). The decrease in the incidences of testicular interstitial cell adenoma in F344/N male rats, a neoplasm common to this strain (Haseman et al., 1998), also suggests that androstenedione administration had a similar effect in this 2-year study. The origination of testicular interstitial cell adenoma is thought to be through endocrinemediated mechanisms (Cook et al., 1999), which androstenedione administration may have alleviated. Oxymetholone administration had a similar effect on testicular adenomas in rats (NTP, 1999). A previous study that administered testosterone, estradiol, or a luteinizing hormone (LH) receptor agonist to Fisher 344 rats demonstrated that these hormones reduced the high levels of circulating LH in older animals and inhibited formation of Leydig cell adenomas (Chatani et al., 1990). Androstenedione, or an androstenedione metabolite, likely had a similar effect on circulating LH levels, which is believed to be a stimulating factor for interstitial cell adenoma formation in the Fisher 344/N rat testis.

In the chronic mouse study, androstenedione was carcinogenic in male and female mouse liver. Although $\mathrm{B} 6 \mathrm{C} 3 \mathrm{~F} 1$ mice have a high background rate of liver tumors, males more so than females, the increase in adenomas, multiple adenomas and carcinomas, and marginal 
increase in hepatoblastomas indicates carcinogenic activity in the male mouse liver. In female mice, androstenedione increased the incidence of adenomas and carcinomas and multiple carcinomas. In contrast, male and female rats displayed no evidence of androstenedione-induced hepatocellular neoplasms, which may be due to differences in metabolism between the two species and/or genetic susceptibility. Androstenedione carcinogenicity within the liver is consistent with other androgens, which are known hepatocellular carcinogens (IARC, 1987). The incidence of these neoplasms in mice might have declined if androstenedione administration had been stopped. Stopping treatment with oxymetholone, a human liver carcinogen, results in regression of hepatic tumors (Fremond et al., 1987; Montgomery et al., 1980; Obeid et al., 1980; Velazquez and Alter, 2004). The androgen receptor also contributes to tumor promotion in the liver. Male mice lacking a functional androgen receptor in the liver have a considerably lower prevalence of hepatocellular tumors after a $N, N$-diethylnitrosamine challenge compared to wildtype mice (Kemp et al., 1989).

The increase of pancreatic islet cell adenomas, a rare neoplasm, was considered related to androstenedione administration due to the incidence in the $50 \mathrm{mg} / \mathrm{kg}$ group exceeding concurrent and historical control rates from all routes of administration. Male mice had a similar increase at the high dose, which also was considered related to androstenedione administration since it exceeded the historical control range from all routes of exposure. In addition, the day of first incidence decreased with increasing dose in male mice, which is supportive of an effect in the pancreas. It is not clear by what mechanism androstenedione administration would induce these neoplasms, but the mouse pancreatic islet $\beta$ cells express the androgen receptor, which may play a role in $\beta$-cell proliferation (Li et al., 2008). CYP 17 , the steroidogenic enzyme responsible for converting progestins to androgens, has been identified in rat pancreatic islets (Ogishima et al., 2008), but has yet to be identified in mouse islet cells. The relation of androgens, pancreatic islet cells, and insulin is not well understood, but it is of interest due to polycystic ovary syndrome, in which individuals have increased levels of circulating androstenedione, and decreased insulin sensitivity (Schuring et al., 2008).

The decrease in the incidence of malignant lymphoma in female mice, a common type of neoplasm for this strain (Haseman et al., 1998), may be due to endocrine action since the immune system is sensitive to steroids (Beagley and Gockel, 2003; Bouman et al., 2005). Male B6C3F1 mice have a considerably lower background rate of malignant lymphoma compared to the female mice (average: $3 \%$ versus $21 \%$ for all routes), and the androgen action of androstenedione could be responsible for reducing malignant lymphoma incidence in female mice.

Androstenedione administration resulted in histological changes, indicating masculinization, in the kidney (Figure 1), submandibular salivary gland (Figure 2), and clitoral gland of female mice. The submandibular salivary gland is a sexually dimorphic and androgensensitive tissue. The withdrawal of androgens in male mice results in demasculinization within this gland and administration of androgens to females induces masculinization (Chretien, 1977; Kronman and Spinale, 1965; Sawada and Noumura, 1991). In addition to the submandibular gland changes, androstenedione administration resulted in glomerulus metaplasia in female mice, an appearance similar to that of the male mouse. This effect within the female mouse glomerulus was also noted after oxymetholone administration (NTP, 1999). The hormonal responsiveness of the clitoral gland to androgens is not well understood (Traish et al., 2002), but the increased incidence of clitoral gland hyperplasia in female mice may be related to the androgenic effects of androstenedione. 
There were similar findings between oxymetholone and androstenedione in the chronic exposure rat gavage studies (Table 8), but there were some noted differences. Oxymetholone is a potent anabolic steroid, but it displays poor androgen receptor binding, while androstenedione binds the androgen receptor, albeit less potently than dihydrotestosterone, and displays limited evidence of an anabolic effect (Jasuja et al., 2005; Kicman, 2008; Saartok et al., 1984). In the chronic study, oxymetholone increased neoplasm incidences in the liver and skin of female rats, while androstenedione did not. The differences in liver tumor incidence may be related to differences in metabolism. The 17' methyl group within oxymetholone decreases the rate of liver metabolism and $17 \alpha$-alkylated androgens have side effects of hepatotoxicity (Snyder, 2001). However, androstenedione, as an endogenous non-17' methylated hormone, likely has a faster metabolism. The skin neoplasms observed with oxymetholone-treated female rats may be related to oxymethalone's anabolic activity, as anabolic steroids induce skin lesions, and oxymetholone accumulates within this site (NTP, 1999). In contrast there is limited evidence of anabolic activity by androstenedione (Jasuja et al., 2005). The effects of diet, NIH-07 for oxymetholone versus NTP-2000 for androstenedione, on outcome are not known, but dietary differences may also be a contributing factor in differences between the two studies.

In summary, there was clear evidence of androstenedione carcinogenic activity in the mouse liver, which is generally consistent with other androgens. The pancreatic islet adenomas in male and female mice were considered to be related to androstenedione administration. The incidences, both increases and decreases, of neoplasia in rodents administered androstenedione were generally similar to oxymetholone, an anabolic androgen. The exceptions may be due to differences in androgen receptor binding, metabolism, and anabolic activity. In male and female rats, there was equivocal evidence of carcinogenic activity based on lung neoplasms and mononuclear cell leukemia, respectively.

Androstenedione administration reduced the incidence of neoplasms in several tissues that are well known endocrine targets, suggesting an ameliorative effect within these tissues, possibly due to compensation for adverse endocrine-mediated mechanisms that arise during the aging process.

\section{Acknowledgments}

This research was supported in part by the Intramural Research Program of the NIH, NIEHS under Research Project Number 1 Z01 ES045004-11 BB and contract number N01-ES-35514.

\section{References}

Bahrke MS, Yesalis CE. Abuse of anabolic androgenic steroids and related substances in sport and exercise. Curr Opin Pharmacol. 2004; 4:614-620. [PubMed: 15525553]

Bailer AJ, Portier CJ. Effects of treatment-induced mortality and tumor-induced mortality on tests for carcinogenicity in small samples. Biometrics. 1988; 44:417-431. [PubMed: 3390507]

Beagley KW, Gockel CM. Regulation of innate and adaptive immunity by the female sex hormones oestradiol and progesterone. FEMS Immunol Med Microbiol. 2003; 38:13-22. [PubMed: 12900050]

Beamer WG, Shultz KL, Tennent BJ. Induction of ovarian granulosa cell tumors in SWXJ-9 mice with dehydroepiandrosterone. Cancer Res. 1988; 48:2788-2792. [PubMed: 2965969]

Beckham SG, Earnest CP. Four weeks of androstenedione supplementation diminishes the treatment response in middle aged men. Br J Sports Med. 2003; 37:212-218. [PubMed: 12782545]

Bischoff F. Cocarcinogenic activity of cholesterol oxidation products and sesame oil. J Natl Cancer Inst. 1957; 19:977-987. [PubMed: 13507698]

Bouman A, Heineman MJ, Faas MM. Sex hormones and the immune response in humans. Hum Reprod Update. 2005; 11:411-423. [PubMed: 15817524] 
Broeder CE, Quindry J, Brittingham K, Panton L, Thomson J, Appakondu S, Breuel K, Byrd R, Douglas J, Earnest C, Mitchell C, Olson M, Roy T, Yarlagadda C. The Andro Project: physiological and hormonal influences of androstenedione supplementation in men 35 to 65 years old participating in a high-intensity resistance training program. Arch Intern Med. 2000; 160:30933104. [PubMed: 11074738]

Brown GA, Dewey JC, Brunkhorst JA, Vukovich MD, King DS. Changes in serum testosterone and estradiol concentrations following acute androstenedione ingestion in young women. Horm Metab Res. 2004a; 36:62-66. [PubMed: 14983409]

Brown GA, Vukovich MD, King DS. Urinary excretion of steroid metabolites after chronic androstenedione ingestion. J Clin Endocrinol Metab. 2004b; 89:6235-6238. [PubMed: 15579782]

Chatani F, Nonoyama T, Sudo K, Miyajima H, Takeyama M, Takatsuka D, Mori H, Matsumoto K. Stimulatory effect of luteinizing hormone on the development and maintenance of 5 alpha-reduced steroid-producing testicular interstitial cell tumors in Fischer 344 rats. Anticancer Res. 1990; 10:337-342. [PubMed: 2189360]

Chretien M. Action of testosterone on the differentiation and secretory activity of a target organ: the submaxillary gland of the mouse. Int Rev Cytol. 1977; 50:333-396. [PubMed: 332658]

Cook JC, Klinefelter GR, Hardisty JF, Sharpe RM, Foster PM. Rodent Leydig cell tumorigenesis: a review of the physiology, pathology, mechanisms, and relevance to humans. Crit Rev Toxicol. 1999; 29:169-261. [PubMed: 10213111]

Cox DR. Regression models and life-tables. Journal of the Royal Statistical Society. 1972; 34:187220.

Dauvois S, Labrie F. Androstenedione and androst-5-ene-3 beta,17 beta-diol stimulate DMBA-induced rat mammary tumors--role of aromatase. Breast Cancer Res Treat. 1989; 13:61-69. [PubMed: 2495831]

Dunnett CW. A mulitple comparison procedure for comparing several treatments with a control. Journal of the American Statistical Association. 1955; 50:1096-1121.

Fremond B, Jouan H, Sameh AH, Le Gall E, Bergeron C, Manac'h A, Gruel Y, Babut JM. Tumors of the liver secondary to androgen therapy. Apropos of 2 cases in children. Chir Pediatr. 1987; 28:97-101. [PubMed: 3040281]

Haseman JK, Hailey JR, Morris RW. Spontaneous neoplasm incidences in Fischer 344 rats and B6C3F1 mice in two-year carcinogenicity studies: a National Toxicology Program update. Toxicol Pathol. 1998; 26:428-441. [PubMed: 9608650]

Holmes PV, Dickson AD. X-zone degeneration in the adrenal glands of adult and immature female mice. J Anat. 1971; 108:159-168. [PubMed: 4322581]

IARC. IARC Monographs on the Evaluation of Carcinogenic Risks to Humans Overall Evaluations of Carcinogenicity: An Updating of IARC Monographs. 1987. p. 96-98.

Ingerowski GH, Scheutwinkel-Reich M, Stan HJ. Mutagenicity studies on veterinary anabolic drugs with the Salmonella/microsome test. Mutat Res. 1981; 91:93-98. [PubMed: 7019696]

Jasuja R, Ramaraj P, Mac RP, Singh AB, Storer TW, Artaza J, Miller A, Singh R, Taylor WE, Lee ML, Davidson T, Sinha-Hikim I, Gonzalez-Cadavid N, Bhasin S. Delta-4-androstene-3,17-dione binds androgen receptor, promotes myogenesis in vitro, and increases serum testosterone levels, fat-free mass, and muscle strength in hypogonadal men. J Clin Endocrinol Metab. 2005; 90:855863. [PubMed: 15522925]

Kaplan EL, Meier P. Nonparametric estimation from incomplete observations. Journal of the American Statistical Association. 1958; 53:457-481.

Kemp CJ, Leary CN, Drinkwater NR. Promotion of murine hepatocarcinogenesis by testosterone is androgen receptor-dependent but not cell autonomous. Proc Natl Acad Sci U S A. 1989; 86:75057509. [PubMed: 2798421]

Kicman AT. Pharmacology of anabolic steroids. Br J Pharmacol. 2008; 154:502-521. [PubMed: 18500378]

King DS, Sharp RL, Vukovich MD, Brown GA, Reifenrath TA, Uhl NL, Parsons KA. Effect of oral androstenedione on serum testosterone and adaptations to resistance training in young men: a randomized controlled trial. Jama. 1999; 281:2020-2028. [PubMed: 10359391] 
Kronman JH, Spinale JJ. A histochemical study of testosterone-induced changes in the submandibular and sublingual gland of mice. Am J Anat. 1965; 117:417-431. [PubMed: 4160088]

Leder BZ, Leblanc KM, Longcope C, Lee H, Catlin DH, Finkelstein JS. Effects of oral androstenedione administration on serum testosterone and estradiol levels in postmenopausal women. J Clin Endocrinol Metab. 2002; 87:5449-5454. [PubMed: 12466335]

Leder BZ, Longcope C, Catlin DH, Ahrens B, Schoenfeld DA, Finkelstein JS. Oral androstenedione administration and serum testosterone concentrations in young men. Jama. 2000; 283:779-782. [PubMed: 10683057]

Li RJ, Qiu SD, Wang HX, Tian H, Wang LR, Huo YW. Androgen receptor: a new player associated with apoptosis and proliferation of pancreatic beta-cell in type 1 diabetes mellitus. Apoptosis. 2008; 13:959-971. [PubMed: 18543106]

McKillop CA, Owen RW, Bilton RF, Haslam EA. Mutagenicity testing of steroids obtained from bile acids and cholesterol. Carcinogenesis. 1983; 4:1179-1183. [PubMed: 6349845]

Metzger C, Mayer D, Hoffmann H, Bocker T, Hobe G, Benner A, Bannasch P. Sequential appearance and ultrastructure of amphophilic cell foci, adenomas, and carcinomas in the liver of male and female rats treated with dehydroepiandrosterone. Toxicol Pathol. 1995; 23:591-605. [PubMed: 8578102]

Montgomery RR, Ducore JM, Githens JH, August CS, Johnson ML. Regression on oxymetholoneinduced hepatic tumors after bone marrow transplantation in aplastic anemia. Transplantation. 1980; 30:90-96. [PubMed: 7010713]

Morrison, DF. Multivariate Statistical Methods. 2nd ed. McGraw-Hill Book Company; New York: 1976.

NTP. NTP Toxicology and Carcinogenesis Studies of Oxymetholone (CAS NO. 434-07-1) in F344/N Rats and Toxicology Studies of Oxymetholone in B6C3F1 Mice (Gavage Studies). Natl Toxicol Program Tech Rep Ser. 1999; 485:1-233. [PubMed: 12571678]

NTP. Estrogens, steroidal. Rep Carcinog. 2002; 10:116-119. [PubMed: 15323057]

NTP. NTP Toxicology and Carcinogenesis Studies of Androstenedione (CAS NO. 63-05-8) in F344/N Rats and B6C3F1 Mice (Gavage Studies). Natl Toxicol Program Tech Rep Ser. 2010; 560:1-233. [PubMed: 21037592]

Obeid DA, Hill FG, Harnden D, Mann JR, Wood BS. Fanconi anemia. Oxymetholone hepatic tumors, and chromosome aberrations associated with leukemic transition. Cancer. 1980; 46:1401-1404. [PubMed: 6251960]

Ogishima T, Mitani F, Suematsu M. Cytochrome P-450(17alpha) in beta-cells of rat pancreas and its local steroidogenesis. J Steroid Biochem Mol Biol. 2008; 111:80-86. [PubMed: 18556192]

Orner GA, Mathews C, Hendricks JD, Carpenter HM, Bailey GS, Williams DE. Dehydroepiandrosterone is a complete hepatocarcinogen and potent tumor promoter in the absence of peroxisome proliferation in rainbow trout. Carcinogenesis. 1995; 16:2893-2898. [PubMed: 8603461]

Portier CJ, Bailer AJ. Testing for increased carcinogenicity using a survival-adjusted quantal response test. Fundam Appl Toxicol. 1989; 12:731-737. [PubMed: 2744275]

Rao GN. New diet (NTP-2000) for rats in the National Toxicology Program toxicity and carcinogenicity studies. Fundam Appl Toxicol. 1996; 32:102-108. [PubMed: 8812243]

Rao MS, Subbarao V, Yeldandi AV, Reddy JK. Hepatocarcinogenicity of dehydroepiandrosterone in the rat. Cancer Res. 1992; 52:2977-2979. [PubMed: 1316232]

Robaire B, Ewing LL, Irby DC, Desjardins C. Interactions of testosterone and estradiol-17 beta on the reproductive tract of the male rat. Biol Reprod. 1979; 21:455-463. [PubMed: 486667]

Robaire B, Smith S, Hales BF. Suppression of spermatogenesis by testosterone in adult male rats: effect on fertility, pregnancy outcome and progeny. Biol Reprod. 1984; 31:221-230. [PubMed: 6089920]

Saartok T, Dahlberg E, Gustafsson JA. Relative binding affinity of anabolic-androgenic steroids: comparison of the binding to the androgen receptors in skeletal muscle and in prostate, as well as to sex hormone-binding globulin. Endocrinology. 1984; 114:2100-2106. [PubMed: 6539197]

Sawada K, Noumura T. Effects of castration and sex steroids on sexually dimorphic development of the mouse submandibular gland. Acta Anat (Basel). 1991; 140:97-103. [PubMed: 1867061] 
Schuring AN, Schulte N, Sonntag B, Kiesel L. Androgens and insulin--two key players in polycystic ovary syndrome. Recent concepts in the pathophysiology and genetics of polycystic ovary syndrome. Gynakol Geburtshilfliche Rundsch. 2008; 48:9-15. [PubMed: 18209494]

Shelby MD, Erexson GL, Hook GJ, Tice RR. Evaluation of a three-exposure mouse bone marrow micronucleus protocol: results with 49 chemicals. Environ Mol Mutagen. 1993; 21:160-179. [PubMed: 8444144]

Shirley E. A non-parametric equivalent of Williams' test for contrasting increasing dose levels of a treatment. Biometrics. 1977; 33:386-389. [PubMed: 884197]

Snyder, PJ. Goodman \& Gilman's: The pharmacological basis of therapeutics. 10th ed. McGraw-Hill; 2001.

Tarone RE. Tests for trend in life table analysis. Biometrika. 1975; 62:679-690.

Tomooka Y, Yasui T. Electron microscopic study of the response of the adrenocortical X-zone in mice treated with sex steroids. Cell Tissue Res. 1978; 194:269-277. [PubMed: 728964]

Traish AM, Kim N, Min K, Munarriz R, Goldstein I. Role of androgens in female genital sexual arousal: receptor expression, structure, and function. Fertil Steril. 2002; 77(Suppl 4):S11-18. [PubMed: 12007897]

Tsutsui T, Komine A, Huff J, Barrett JC. Effects of testosterone, testosterone propionate, 17 betatrenbolone and progesterone on cell transformation and mutagenesis in Syrian hamster embryo cells. Carcinogenesis. 1995; 16:1329-1333. [PubMed: 7788850]

Velazquez I, Alter BP. Androgens and liver tumors: Fanconi's anemia and non-Fanconi's conditions. Am J Hematol. 2004; 77:257-267. [PubMed: 15495253]

Wheeler WJ, Cherry LM, Downs T, Hsu TC. Mitotic inhibition and aneuploidy induction by naturally occurring and synthetic estrogens in Chinese hamster cells in vitro. Mutat Res. 1986; 171:31-41. [PubMed: 3724781]

Williams DA. A test for differences between treatment means when several doses levels are compared with a zero dose control. Biometrics. 1971; 27:103-117. [PubMed: 5547548]

Williams DA. The comparison of several dose levels with a zero dose control. Biometrics. 1972; 28:519-531. [PubMed: 5037867]

Witt KL, Knapton A, Wehr CM, Hook GJ, Mirsalis J, Shelby MD, MacGregor JT. Micronucleated erythrocyte frequency in peripheral blood of $\mathrm{B} 6 \mathrm{C} 3 \mathrm{~F}(1)$ mice from short-term, prechronic, and chronic studies of the NTP carcinogenesis bioassay program. Environ Mol Mutagen. 2000; 36:163-194. [PubMed: 11044899]

Zieger E, Anderson B, Haworth S, Lawlor T, Mortelmans K. Salmonella mutagenicity tests: V. Results from the testing of 311 chemicals. Environmental and Molecular Mutagenesis. 1992; 19:2-141. [PubMed: 1541260] 
Androstenedione manuscript highlights for Food and Chemical Toxicology

- We investigated the chronic toxicity and carcinogenicity activityof androstenedione

- Androstenedione may or may not carcinogenic in F344/N rats

- Androstenedione was carcinogenic in $\mathrm{B} 6 \mathrm{C} 3 \mathrm{~F} 1$ mice

- Androstenedione decreased tumors in endocrine sensitive reproductive organs 
Figure 1.

Glomerular metaplasia in female mice. In male mice this epithelium is normally cuboidal whereas in female mice it is normally flattened. A) kidney image from a female mouse in the control group. Note the flattened parietal epithelium lining Bowman's capsule (indicated by arrows). B) kidney image from a female mouse in the high dose group. The parietal epithelium lining Bowman's capsule is cuboidal, similar to males. 
Figure 2.

Submandibular gland cytoplasmic alteration in female mice. In male mice the ducts are larger and contain more intracytoplasmic granular material than females. A) salivary gland image from a female mouse in the control group. B) salivary gland image from a female mouse in the high dose group with larger ducts and increased amount of eosinophilic intraductal material (indicated by arrows). 


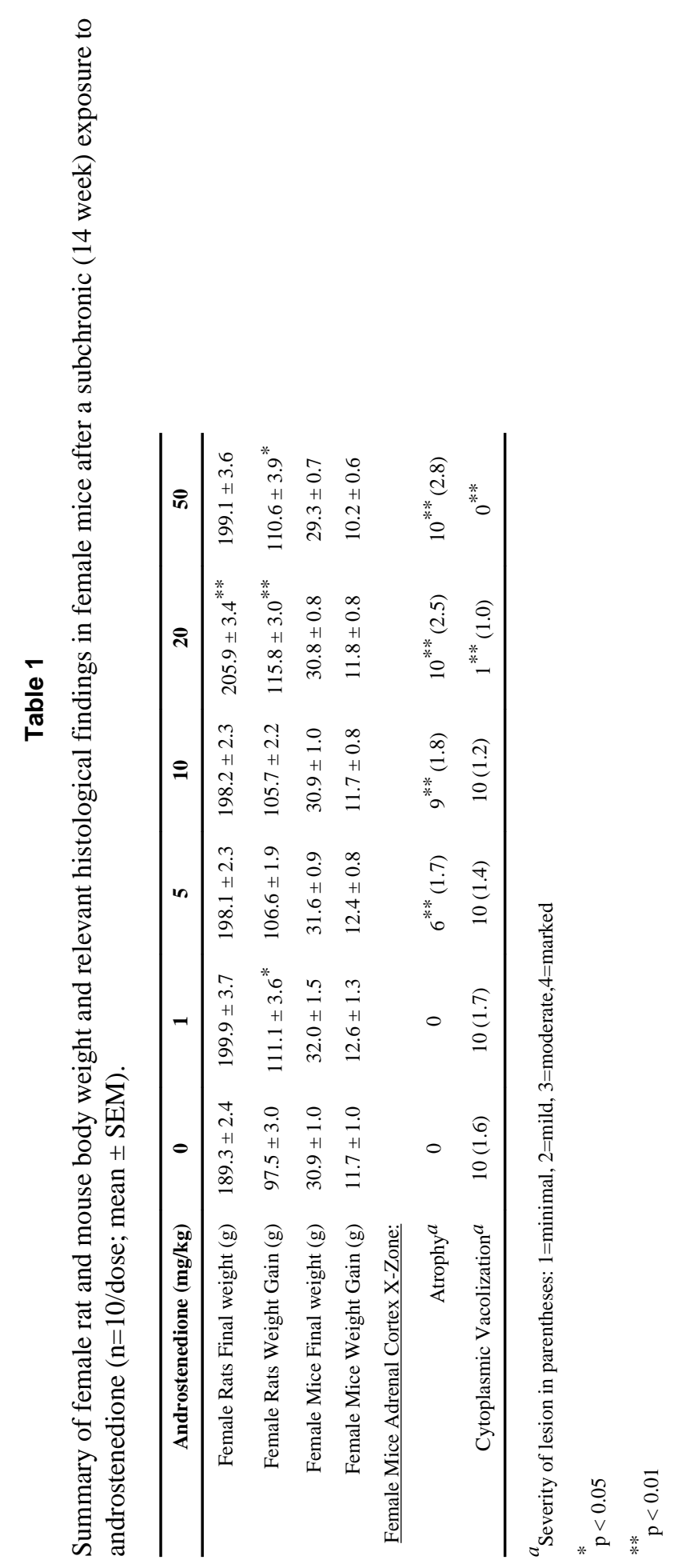


Table 2

Summary of andrology results after subchronic androstenedione exposure to male B6C3F1 mice and F344/N rats $(n=10 /$ dose; mean \pm SEM $)$.

\begin{tabular}{|c|c|c|c|c|}
\hline Androstenedione (mg/kg) & $\mathbf{0}$ & 10 & 20 & 50 \\
\hline Rat Spermatid heads ( $10^{3} / \mathrm{mg}$ testis) & $124.9 \pm 3.3$ & $127.1 \pm 4.8^{a}$ & $131.8 \pm 4.5$ & $126.50 \pm 3.6$ \\
\hline Rat Spermatid heads ( $10^{6} /$ testis) & $169.4 \pm 5.5$ & $172.1 \pm 4.1^{a}$ & $178.0 \pm 6.9$ & $169.4 \pm 5.9$ \\
\hline Rat Sperm $\left(10^{3} / \mathrm{mg}\right.$ cauda epi) & $575 \pm 27$ & $475 \pm 28 *$ & $463 \pm 27^{*}$ & $407 \pm 21^{* *}$ \\
\hline Rat Sperm (10\% cauda epi) & $112 \pm 5$ & $98 \pm 5$ & $95 \pm 6$ & $85 \pm 5^{* *}$ \\
\hline Rat Sperm motility (\%) & $75.7 \pm 2.2$ & $76.0 \pm 2.1$ & $73.8 \pm 2.4$ & $74.7 \pm 1.5$ \\
\hline Mouse Spermatid heads ( $10^{3} / \mathrm{mg}$ testis) & $189.5 \pm 3.3$ & $208.7 \pm 11.0$ & $219.2 \pm 11.3^{*}$ & $209.8 \pm 11.3$ \\
\hline Mouse Spermatid heads $\left(10^{6} /\right.$ testis $)$ & $19.4 \pm 0.7$ & $22.2 \pm 1.0$ & $23.3 \pm 1.1 *$ & $20.9 \pm 0.8$ \\
\hline Mouse Sperm ( $10^{3} / \mathrm{mg}$ cauda epi.) & $780 \pm 110$ & $958 \pm 54$ & $840 \pm 54$ & $879 \pm 77$ \\
\hline Mouse Sperm (10\% cauda epi) & $18 \pm 2$ & $19 \pm 1$ & $18 \pm 1$ & $19 \pm 1$ \\
\hline Mouse Sperm motility (\%) & $67.2 \pm 4.4$ & $67.2 \pm 2.5$ & $68.8 \pm 1.4$ & $56.7 \pm 3.9^{* *}$ \\
\hline \multicolumn{5}{|l|}{$a_{\mathrm{n}=9}$} \\
\hline \multicolumn{5}{|l|}{$\mathrm{p}<0.05$} \\
\hline${ }^{* *} \quad \mathrm{p}<0.01$ & & & & \\
\hline
\end{tabular}


Table 3

Incidences of lung, testis, mammary gland neoplastic and non-neoplastic lesions in male and female F344/N rats after chronic exposure to androstenedione.

\begin{tabular}{|c|c|c|c|c|}
\hline \multirow[b]{2}{*}{ Tissue Lesion } & \multicolumn{4}{|c|}{ Androstenedione (mg/kg) } \\
\hline & $\mathbf{0}$ & 10 & 20 & 50 \\
\hline Mononuclear Cell Leukemia (male) ${ }^{b}$ & $26 / 50(59.0)^{a}$ & $22 / 50(47.8)$ & $18 / 50(39.9)^{*}$ & $18 / 50(39.2)^{*}$ \\
\hline Mononuclear Cell Leukemia (female) ${ }^{c}$ & $5 / 50(10.4)$ & $11 / 50(23.3)$ & $18 / 50(38.4)$ & $15 / 50(30.3)$ \\
\hline Alveolar bronchiolar Adenoma (male) ${ }^{d}$ & $0 / 50(0)$ & $0 / 50(0)$ & $5 / 50(11.6)$ & $2 / 50(4.6)$ \\
\hline Alveolar bronchiolar Adenoma or Carcinoma (male) ${ }^{e}$ & $0 / 50(0)$ & $0 / 50(0)$ & $5 / 50(11.6)$ & $3 / 50(6.9)$ \\
\hline Interstitial Cell Adenoma (male) & $42 / 50(91.1)$ & $39 / 50(83.8)$ & $36 / 50(79.2)$ & $26 / 50(58.1)^{* * *}$ \\
\hline Interstitial Cell Adenoma - Bilateral & $29 / 50$ & $29 / 50$ & $28 / 50$ & $10 / 50^{* *}$ \\
\hline First Incidence (days) & 464 & 540 & 558 & 607 \\
\hline \multicolumn{5}{|l|}{ Mammary Gland (female) } \\
\hline Hyperplasia $f$ & $48[2.2]$ & $40 * *[2.3]$ & $35^{* *}[2.0]$ & $23^{* *}[1.8]$ \\
\hline Cyst $f^{f}$ & $15[2.1]$ & $3^{* *}[1.7]$ & $9[2.1]$ & $3^{* *}[2.7]$ \\
\hline Fibroadenoma & $35(72.3)$ & $31(66.1)$ & $22(47.6)^{* *}$ & $12(26.9)^{* * *}$ \\
\hline Multiple Fibroadenomas & 17 & 13 & $6^{* *}$ & $3^{* *}$ \\
\hline Fibroadenoma, Adenoma, or Carcinoma & $37(75.7)$ & $32(68.2)$ & $22(47.6)^{* *}$ & $12(26.9)^{* * *}$ \\
\hline \multicolumn{5}{|c|}{ Poly-3 estimated neoplasm incidence after adjustment for mortality in parentheses } \\
\hline \multicolumn{5}{|c|}{ Historical control incidence: methylcellulose vehicle $49 / 100$, range $46-52 \%$ (unadjusted); all routes $553 / 1399$ range $8-58 \%$} \\
\hline \multicolumn{5}{|c|}{${ }^{c}$ Historical control incidence: methylcellulose vehicle $17 / 100$, range $10-24 \%$ (unadjusted); all routes $297 / 1350$, range $8-40 \%$} \\
\hline \multicolumn{5}{|c|}{${ }^{d}$ Historical control incidence: methylcellulose vehicle $1 / 100$, range $0-2 \%$ (unadjusted); all routes $34 / 1399$, range $0-8 \%$} \\
\hline \multicolumn{5}{|c|}{${ }^{e}$ Historical control incidence: methylcellulose vehicle $1 / 100$, range $0-2 \%$ (unadjusted); all routes $47 / 1399$, range $0-10 \%$} \\
\hline \multicolumn{5}{|c|}{$f_{\text {Severity of lesion in brackets: } 1=\text { minimal, } 2=\text { mild, } 3=\text { moderate }, 4=\text { marked }}$} \\
\hline \multicolumn{5}{|c|}{$*<<0.05$} \\
\hline \multicolumn{5}{|l|}{ ** $\mathrm{p}<0.01$} \\
\hline **** $\mathrm{p}<0.001$ & & & & \\
\hline
\end{tabular}


Table 4

Incidences of hepatocellular neoplastic lesions in male and female $\mathrm{B} 6 \mathrm{C} 3 \mathrm{~F} 1$ mice after a chronic exposure.

\begin{tabular}{|c|c|c|c|c|}
\hline \multirow{2}{*}{$\begin{array}{l}\text { Tissue Lesion } \\
\underline{\text { Males }}\end{array}$} & \multicolumn{4}{|c|}{ Androstenedione $^{a}$} \\
\hline & $0 \mathrm{mg} / \mathrm{kg}$ & $10 \mathrm{mg} / \mathrm{kg}$ & $20 \mathrm{mg} / \mathrm{kg}$ & $50 \mathrm{mg} / \mathrm{kg}$ \\
\hline Adenoma & $32(71.2)$ & $38(78.6)$ & $29(63.9)$ & $43(91.8)^{* *}$ \\
\hline Adenoma Multiples & 16 & $27^{*}$ & 23 & $34^{* *}$ \\
\hline Carcinoma & 26 & 33 & 28 & 32 \\
\hline Carcinoma Multiples & 7 & $12^{* *}$ & 10 & $17^{* *}$ \\
\hline Blastomas & $3(6.9)$ & $8(16.4)$ & $7(15.7)$ & $8(17.6)$ \\
\hline Carcinoma Multiples & 0 & 1 & 1 & 3 \\
\hline $\mathrm{A}, \mathrm{C}$, or $\mathrm{HB}^{b}$ & $41(85.2)$ & $47(94.1)$ & $43(89.4)$ & $48(98.5)^{*}$ \\
\hline$\underline{\text { Females }}$ & $0 \mathrm{mg} / \mathrm{kg}$ & $2 \mathrm{mg} / \mathrm{kg}$ & $10 \mathrm{mg} / \mathrm{kg}$ & $50 \mathrm{mg} / \mathrm{kg}$ \\
\hline Adenoma & $14(31.6)$ & $16(34.6)$ & $18(39.1)$ & $28(61.1)^{* *}$ \\
\hline Adenoma Multiples & 4 & 7 & 7 & $17^{* *}$ \\
\hline Carcinoma & $5(11.3)$ & $13(28.2)^{*}$ & $15(32.0)^{*}$ & $15(32.7)^{*}$ \\
\hline Carcinoma Multiples & 1 & 2 & 5 & 4 \\
\hline $\mathrm{A}, \mathrm{C}$, or $\mathrm{HB}$ & $17(38.2)$ & $23(49.5)$ & $27(57.0)$ & $32(69.8)^{* * *}$ \\
\hline
\end{tabular}

${ }^{a}$ Poly-3 estimated percent incidence after adjustment for mortality in parentheses

${ }^{b} \mathrm{~A}=$ adenoma, $\mathrm{C}=$ carcinoma, $\mathrm{HB}=$ hepatoblastoma

* $\mathrm{p}<0.05$

$* *$

$\mathrm{p}<0.01$

*** $\mathrm{p}<0.001$ 


\section{Table 5}

Incidences of non-neoplastic lesions of the pancreas and islet cell adenomas in male and female B6C3F1 mice after chronic exposure to androstenedione via gavage.

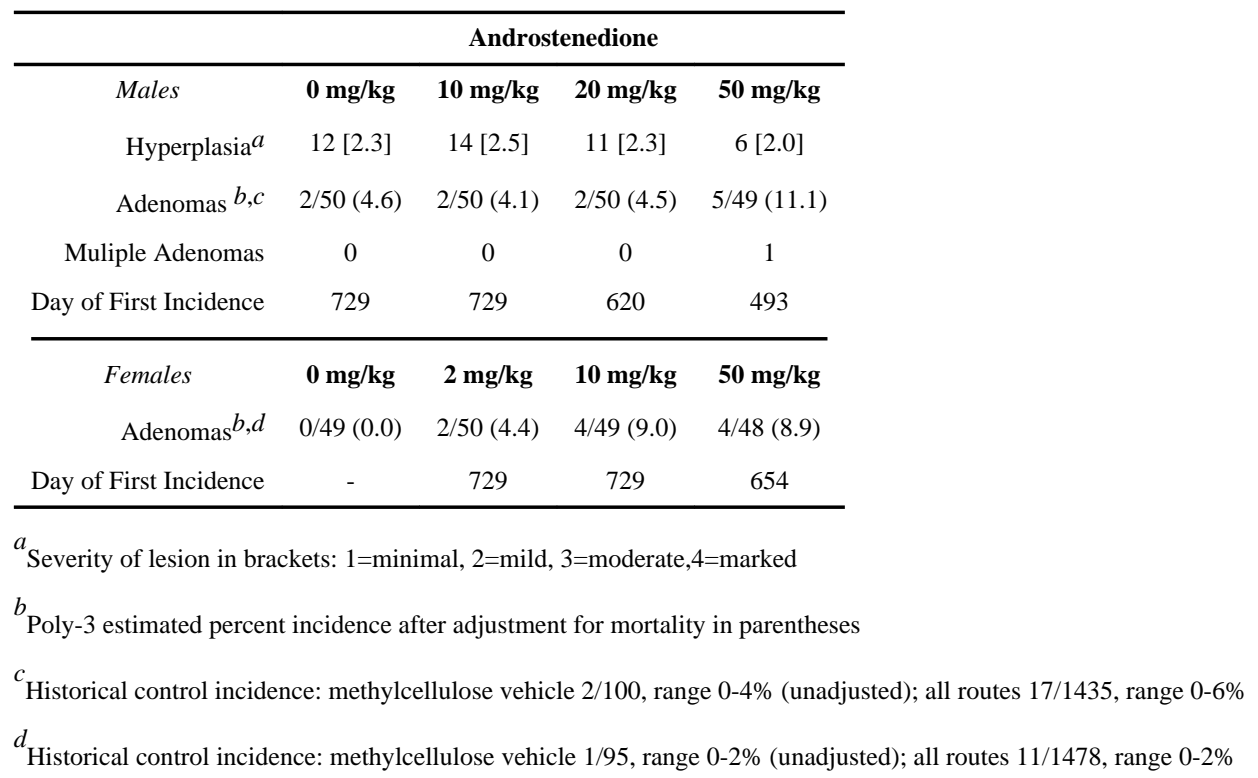


Table 6

Incidences of non-neoplastic lesions in female B6C3F1 mice after chronic exposure to androstenedione via gavage.

\begin{tabular}{rcccc}
\hline & \multicolumn{4}{c}{ Androstenedione (mg/kg) } \\
Tissue Lesion $^{a}$ & $\mathbf{0}$ & $\mathbf{2}$ & $\mathbf{1 0}$ & $\mathbf{5 0}$ \\
\hline Clitoral Gland Hyperplasia $^{b}$ & $0 / 47$ & $2 / 47[1.0]$ & $13 / 49^{* *}[1.9]$ & $41 / 50^{* *}[2.0]$ \\
Clitoral Gland Duct Dilation $^{c}$ & $0 / 47$ & $2 / 47[1.0]$ & $17 / 49^{* *}[1.4]$ & $49 / 50^{* *}[2.6]$ \\
Kidney Glomerulus Metaplasia & $2 / 50[1.5]$ & $1 / 50[2.0]$ & $5 / 50[1.0]$ & $27 / 50^{* *}[2.0]$ \\
Submandibular Salivary Gland Cytoplasmic Alteration & $0 / 49$ & $17 / 49^{* *}[1.2]$ & $40 / 49^{* *}[1.4]$ & $45 / 50^{* *}[2.5]$ \\
\hline
\end{tabular}

${ }^{a}$ Severity of lesion in brackets: $1=$ minimal, 2=mild, 3=moderate,4=marked;

${ }^{b}$ Severity grades for glandular hyperplasia and duct dilatation were based on a semiquantitative evaluation as described in the methods section. ** $\mathrm{p}<0.01$ 


\section{Table 7}

Frequency of MN-PCE (mean \pm SEM) in B6C3F1 mice following administration of androstenedione by gavage for 14 weeks $^{l}$

\begin{tabular}{|c|c|c|c|}
\hline Male mice & & & \\
\hline \multirow{17}{*}{ Female mice } & Dose (mg/kg) & MN-NCE/1000 & $\%$ PCE \\
\hline & 0 & $2.6 \pm 0.51$ & 2.9 \\
\hline & 1 & $2.9 \pm 0.62$ & 2.5 \\
\hline & 5 & $2.8 \pm 0.30$ & 3.0 \\
\hline & 10 & $2.7 \pm 0.54$ & 3.0 \\
\hline & 20 & $2.4 \pm 0.46$ & 2.9 \\
\hline & 50 & $2.1 \pm 0.10$ & 2.5 \\
\hline & \multicolumn{3}{|c|}{ Trend $\mathrm{p}=0.880^{2}$} \\
\hline & & & \\
\hline & Dose $(\mathrm{mg} / \mathrm{kg})$ & MN-NCE/1000 & $\%$ PCE \\
\hline & 0 & $1.6 \pm 0.43$ & 2.8 \\
\hline & 1 & $1.3 \pm 0.20$ & 2.8 \\
\hline & 5 & $1.4 \pm 0.29$ & 3.3 \\
\hline & 10 & $2.0 \pm 0.57$ & 3.2 \\
\hline & 20 & $1.3 \pm 0.12$ & 3.2 \\
\hline & 50 & $3.1 \pm 0.40^{4}$ & 2.6 \\
\hline & \multicolumn{3}{|c|}{ Trend $p=0.001$} \\
\hline Five animals $\mathrm{p}$ & group; NCE, n & mochromatic eryth & rocytes; $\mathrm{P}$ \\
\hline
\end{tabular}




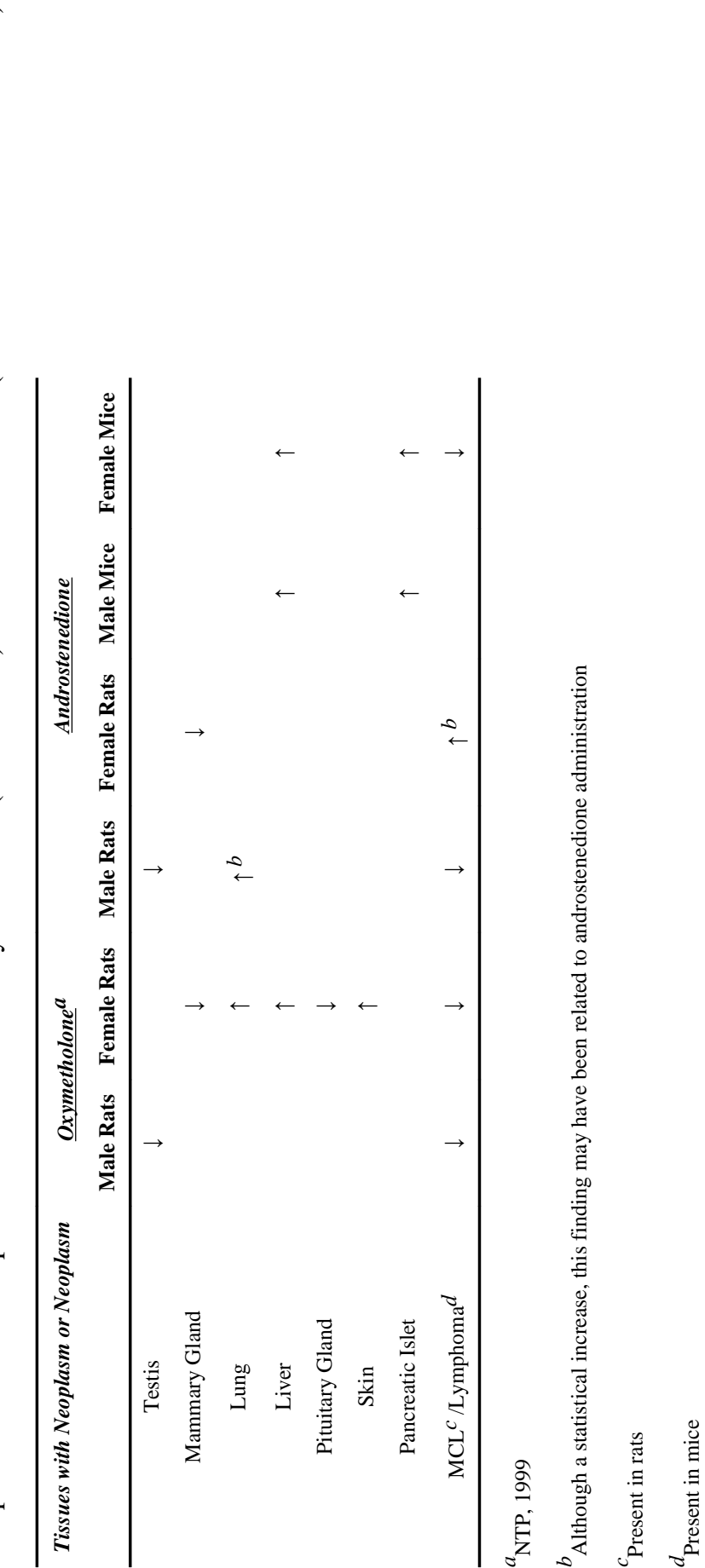

Food Chem Toxicol. Author manuscript; available in PMC 2012 September 1. 